The Gender Pay Gap in the Transition from Communism: Some Empirical Evidence

\author{
By: Andrew Newell and Barry Reilly
}

Working Paper Number 305

May 2000 


\title{
The Gender Pay Gap in the Transition from Communism: Some Empirical Evidence
}

\author{
Andrew Newell and Barry Reilly
}

School of Social Sciences, University of Sussex, Falmer, Brighton BN1 9SN e-mail: a.t.newell@sussex.ac.uk,b.m.reilly@sussex.ac.uk

\begin{abstract}
This short paper investigates the path through the 1990s of the gender pay gap in a number of former communist countries of Eastern Europe and the Soviet Union. The main findings are that the gender pay gap has not exhibited, in general, an upward tendency over the transitional period to which available data relate. Most of the gender pay gap is ascribed to the 'unexplained' component using conventional decompositions and this may be partly attributable to the proxy measure for labour force experience used in this study. Quantile regression analysis indicates that, in all but one country, the ceteris paribus gender pay gap rises as we move up the wage distribution.
\end{abstract}

JEL classification: J160, J310, J700, P230.

Keywords: gender, transition, wage distributions, pay gaps, quantile regression

May 2000 


\section{Introduction}

The process of economic transition in the formerly socialist countries is reshaping the working lives of women. There are new demands made upon women and these affect their ability to contribute time and money to household activity. Women are re-assessing their lifetime decisions, such as when and if to start a family and whether to participate in tertiary education. These changes feed back into and help create the structure of the transitional labour markets. This paper studies one outcome of all these changes, the gap in pay between men and women.

It may be useful to provide a very brief outline of women and work under communism. Like all generalisations, this does not capture the diversity of experience both between and within countries. However, it does help in framing a basis against which to compare the changes documented below. Under socialism women spent more time working, on average, than their Western counterparts. The system of wage and price setting more or less ensured that both adults in a nuclear family would have to work in order to maintain a basic living standard. There was no unemployment in the sense of joblessness. This was partly due to the social stigma that attached to unemployment but has also been attributed to the way hard plan targets and soft budget constraints combined to produce continuous excess demand for labour. Women were accorded a wide range of rights and privileges at work, some of which were formal. In the Soviet system for instance, maternity leave was fully paid and women were legally protected from overly physical and dangerous work. Enterprise kindergartens, schools and health care facilities were fairly commonplace in larger enterprises. Other privileges were informal in nature and perhaps a little dubious (e.g., many women workers tell of being allowed time off to queue in shops).

In terms of occupations and industry branch, women and men were at least as segregated as in the West. Relatively few women held senior positions and this was for two reasons. Firstly, women undertook a very large share of domestic duties thus incurring a double burden and leaving them less time to pursue a career than men. Secondly, the revolution in gender relations in the West, which has brought about a slow but fundamental shift in the household division of labour, did not happen in the communist countries.

Historically, in many centrally planned economies, women's labour market participation was high and gender pay gaps low in comparison to many Western economies. For example, in the former Soviet 
William Davidson Institute Working Paper Number 305

Union (and in the centrally planned economies of Central and Eastern Europe) female participation rates were regularly over 85 percent, while in the West rates of this kind have only recently been observed in some Scandinavian countries. Since 1989 participation has been falling for women in many transitional economies (see UNICEF (1999)). The scale of the collapse in participation in the era of transition is very large. For example, in Poland, a country roughly the size of one of the larger European Union states, about one and a half million female jobs disappeared between 1989 and 1994.

The labour market remains the conduit through which reform policies impact on a country's standard of living (see Horton, Kanbur and Mazumdar (1991)) and is the market through which many of the rewards of transition are transmitted. An interesting question is how the transitional process have been affected the labour market prospects of women. The welfare of both men and women crucially depends on the rate at which the transitional economies recover and develop. Labour market earnings remain an important component of household income in all the transitional economies and provide a direct link between household welfare and economic activity.

In the transitional economies of Central and Eastern Europe (CEE) over the period 1989 to 1995, Allison and Ringold (1996) identified older workers as more vulnerable to unemployment. However, they failed to uncover evidence of a gender dimension to unemployment but noted the decline in female participation in all transitional economies (see also UNICEF (1999)). For the same set of countries covering approximately the same time period, Rutkowski (1996) highlighted the dramatic fall in real wages experienced in all these economies, the increased incidence of low pay, and the steady rise in wage inequality.

There is now a large empirical literature exploring labour market outcomes in the transitional economies. This includes a growing literature investigating the evolution of the wage position of women in the transitional economies (see, e.g., Orasem and Vodopivec (1995) for Slovenia, Orasem and Vodopivec (1999) for Estonia and Slovenia, Brainerd (1999), Glinskaya and Mroz (1996), Newell and Reilly (1996) and Reilly (1999) for Russia, and Hunt (1998) using a sample of East German workers). The purpose of this paper is to add to this literature and examine the trends in the gender pay gap for a selection of transitional economies with a view to assessing whether, in regard to pay, women are gaining, losing or standing still since the collapse of communism.

The following section presents the methodology to be used, outlines some of its limitations, and discusses the empirical results. Section three is devoted to a quantile regression approach to 
William Davidson Institute Working Paper Number 305

computing the ceteris paribus gender pay gap. Section four examines the evolution of the gender pay gap in two countries for which compatible data are available and section five offers some conclusions. 


\section{The Gender Pay Gap}

\subsection{Basic Methodology}

If we denote $\mathrm{W}_{\mathrm{m}}$ and $\mathrm{W}_{\mathrm{f}}$ as wages, a common measure used to summarise the female position in the labour market is the ratio of average female pay to average male pay. This is usually expressed as:

$$
\overline{\mathrm{W}}_{\mathrm{f}}
$$

where the bars denote the average.

This gives the fraction of the average male pay earned by women and is the known as the gender pay ratio. Viewing the male wage as a 'mark-up' on the female wage is generally the dominant approach adopted by economists The use of natural logarithms allows us to compute an average mark-up ( $\overline{\mathrm{D}}$ ) as follows:

$$
\overline{\mathrm{D}}=\overline{\ln \left(\mathbf{W}_{\mathbf{m}}\right)}-\overline{\ln \left(\mathbf{W}_{\mathbf{f}}\right)}
$$

The fundamental problem with either of the expressions [1] or [2] is that, although they may provide an estimate of the gender pay gap, they provide no insight into that part of the gender pay gap, which is attributable to differences in productivity characteristics between the two groups.

In order to inform on gender wage effects, it is useful to control for differences in productivity variables that may exist between gender groups. This requirement demands use of multivariate statistical analysis that allows the researcher to control (or hold constant) other factors, whilst exploring the effect of the characteristic of interest (i.e., gender) on the variable of interest (i.e., the wage). The other factors held constant are usually productivity characteristics and thus wage differences mediated through the characteristic of interest are reflecting wage differences for broadly comparable workers. It has become conventional for economists to specify a relationship between the natural logarithm of earnings and the set of characteristics.

If we define $\mathbf{w}$ as the natural logarithm of $\mathrm{W}$ and specify a wage equation as: 
where $\mathbf{X}$ is a vector of productivity characteristics (e.g., education and labour force experience), and $\mathbf{G}$ is a qualitative variable for gender adopting a value of one if the worker is male and zero if female. $\beta$ is a vector of coefficients representing the effect of the productivity variables on the natural logarithmic wage ( $\mathbf{w})$ and $\mathbf{e}$ is a random error term. The estimation procedure required to provide estimates for the coefficients $\beta$ and $\delta$ is usually Ordinary Least Squares (OLS).

The equation described in [3] can be used to obtain an average estimate for the adjusted gender pay gap. If we denote the OLS estimates for $\beta$ and $\delta$ as $\hat{\beta}$ and $\hat{\delta}$ respectively, we can re-write [3] as:

$$
\hat{\mathrm{w}}=\mathbf{X}^{\prime} \hat{\beta}+\hat{\delta} \mathbf{G}
$$

The adjusted gender pay gap could be written as:

$\mathrm{D}^{\mathrm{A}}=[\hat{\mathrm{w}} \mid \mathbf{X}, \mathbf{G}=1]-[\hat{\mathrm{w}} \mid \mathbf{X}, \mathbf{G}=0]=\hat{\delta}$

Any difference between $\overline{\mathrm{D}}$ and $\hat{\delta}$ (or $\mathrm{D}^{\mathrm{A}}$ ) is therefore attributable to the productivity characteristics contained in the $\mathbf{X}$ vector. The $\hat{\delta}$ simply reflects a parallel shifting upwards of the regression line. In other words, the only part of the estimated relationship allowed to change through the inclusion of a gender variable in this analysis is the estimated intercept term. It may well be the case that the effects of education, labour force experience and other characteristics on earnings differ across gender groups and this pooled regression approach fails to capture this.

The constraint imposed by using a pooled relationship has prompted extensive use of separate equations for men and women. In this approach, we estimate a male equation of the following form:

$$
\mathbf{w}_{\mathbf{m}}=\mathbf{X}_{\mathbf{m}}^{\prime} \beta_{\mathrm{m}}+\mathbf{e}_{\mathbf{m}}
$$


and a female equation of the following form:

$\mathbf{w}_{\mathbf{f}}=\mathbf{X}_{\mathbf{f}}^{\prime} \beta_{\mathrm{f}}+\mathbf{e}_{\mathbf{f}}$

In this case the subscripts $m$ and $f$ denote male and female respectively. It is assumed that the sample of male data points are randomly chosen from the population of males and the sample of female data points are randomly chosen from the population of females.

An important property of the OLS procedure is that the regression plane passes through the means of the data. We could re-write the above expressions as:

$\overline{\mathbf{W}}_{\mathbf{m}}=\overline{\mathbf{X}}_{\mathbf{m}} \hat{\beta}_{\mathrm{m}}$

$\overline{\mathbf{W}}_{\mathbf{f}}=\overline{\mathbf{X}}_{\mathbf{f}}^{\prime} \hat{\beta}_{\mathrm{f}}$

If we recall from above, we could re-write [2] as:

$$
\begin{aligned}
\overline{\ln \left(\mathbf{W}_{\mathbf{m}}\right)}-\overline{\ln \left(\mathbf{W}_{\mathbf{f}}\right)} & =\overline{\mathbf{W}}_{\mathbf{m}}-\overline{\mathbf{W}}_{\mathbf{f}} \\
& =\overline{\mathbf{X}}_{\mathbf{m}} \hat{\beta}_{\mathrm{m}}-\overline{\mathbf{X}}_{\mathbf{f}}^{\prime} \hat{\beta}_{\mathrm{f}}
\end{aligned}
$$

After some manipulation, we can obtain:

$$
=\left[\overline{\mathbf{X}}_{\mathbf{m}}-\overline{\mathbf{X}}_{\mathbf{f}}\right]^{\prime} \hat{\beta}_{\mathrm{m}}+\overline{\mathbf{X}}_{\mathbf{f}}^{\prime}\left[\hat{\beta}_{\mathrm{m}}-\hat{\beta}_{\mathrm{f}}\right]
$$

This allows the overall average differential in wages between the two gender groups to be decomposed into a part attributable to differences in productivity characteristics (as evaluated at the male returns) and a part attributable to differences in the estimated relationship between men and women (i.e., the gender differences in returns). These two components have been referred to as the 'explained' and 'unexplained' components, with the 'unexplained' component also referred to as the 'residual' component (see Blinder (1973) and Oaxaca (1973)). It is the latter part of expression [7], 
which provides the average estimate of the gender pay gap adjusted for productivity characteristics. We could express the last part of expression [7] as:

$\Delta_{\mathrm{UF}}=\overline{\mathbf{X}}_{\mathbf{f}}^{\prime} \Delta \hat{\beta}$

where $\Delta \hat{\beta}=\hat{\beta}_{\mathrm{m}}-\hat{\beta}_{\mathrm{f}}$

This approach is commonly referred to as the 'index number' approach given its similarity to the calculation of index numbers. The use of an 'index number' approach is subject to the famous 'index number' problem. It is clear that expression [9] could be recomputed using the 'basket' of average male characteristics. Under such circumstances, we could re-express [9] as:

$\overline{\ln \left(\mathbf{W}_{\mathbf{m}}\right)}-\overline{\ln \left(\mathbf{W}_{\mathbf{f}}\right)}=\left[\overline{\mathbf{X}}_{\mathbf{m}}-\overline{\mathbf{X}}_{\mathbf{f}}\right]^{\prime} \hat{\beta}_{\mathrm{f}}+\overline{\mathbf{X}}_{\mathbf{m}}\left[\hat{\beta}_{\mathrm{m}}-\hat{\boldsymbol{\beta}}_{\mathrm{f}}\right]$

The last part of this expression could be expressed as:

$\Delta_{\mathrm{UM}}=\overline{\mathbf{X}}_{\mathrm{m}}{ }^{\prime} \Delta \hat{\beta}$

and provides another estimate for the average adjusted gender pay gap based on average male characteristics. Given the 'index number problem', this may be different from expression [8].

Gender pay gap estimates based on $\hat{\delta}, \overline{\mathbf{X}}_{\mathbf{f}}^{\prime}\left[\hat{\beta}_{m}-\hat{\beta}_{f}\right]$ and $\overline{\mathbf{X}}_{m}{ }^{\prime}\left[\hat{\beta}_{m}-\hat{\beta}_{f}\right]$ are computed using a selection of data sets for transitional economies. The standard error for $\hat{\delta}$ is computed using the OLS formula and expressions for the standard errors of the 'index number' quantities are computed in a conventional manner. 


\subsection{Some Methodological Issues}

There are a number of potential problems that attach to use of this particular methodology in identifying an accurate empirical measure of female wage disadvantage. These include, inter alia, the measurement of labour force experience (i.e., actual or potential), the legitimacy of including controls that may reflect the outcome of discriminatory processes (e.g., occupations and industries), and the problem of selection bias.

A key explanatory variable in the analysis of the gender pay gap is labour force experience. Since women generally bear the labour market costs of family formation, their level of labour force experience is likely to be below that of men, and this ultimately impacts on the female wage. The most desirable measure to use in such circumstances is actual labour force experience. Given data constraints this is invariably unavailable and many of our data sets contain insufficient household level information to impute labour force experience. Potential labour force experience can be used but it has been shown that its use assigns a greater portion of the actual wage difference to the unexplained or 'residual' component. For the purposes of our analysis we use age and its quadratic as a proxy measure for labour force experience but acknowledge its limitations in this regard.

The methodology outlined relies on the specification of a well defined human capital model augmented by factors designed to capture compensating differentials and monopoly rents associated with an individual's job or sector of attachment. The validity of the methodology is contingent on the estimated equations providing adequate fits to the data and a stable set of parameter estimates that are consistent with economic theory. This should be borne in mind when interpreting the results obtained using this methodology. It remains a matter of continuing debate as to what controls should (and should not) be included in the specifications. The general evidence is that the greater the number of control variables, the greater the explained portion and the smaller the unexplained portion (i.e., the average productivity adjusted pay gap). If there is gender discrimination by occupation or by industry, then such controls may reflect the outcome of a discriminatory process and could not qualify as legitimate exogenous variables in the wage equation. We acknowledge again this potential problem and in order to provide some insight into the effects on the gender pay gap of adding controls, we provide estimates for both an austere specification with only human capital controls and an 
William Davidson Institute Working Paper Number 305

augmented specification which allows for an array of additional controls including, in most cases industry, occupation and regional controls.

In the context of the potential problems associated with sample selection bias, standard correction procedures can be adopted (see Heckman (1979)). However, they have been subject to much criticism given their sensitivity to identifying restrictions and their general lack of robustness (see Manski, 1989). The absence of adequate identifying restrictions in most of our data sets restricts our ability to address this issue in a satisfactory manner. Thus, the econometric analysis reported in this paper does not deal with the issue of participation selectivity bias.

There are some important methodological issues relating to the measurement of women's wages in the context of transitional economies. The pay measure used in our comparisons relates to earnings received in the main job by employees. The emphasis on main job earnings excludes from the analysis the treatment of secondary earnings. The incidence of secondary job holding has increased in many transitional economies but, to our knowledge, its gender dimension has not been the subject of investigation. Our focus on employees in their main job eliminates measurement errors that would certainly attach to the reporting of earnings on jobs in the secondary or informal sector.

The incidence of payment arrears in a number of the transitional economies (most notably Russia, Ukraine, the Central Asian republics and FR Yugoslavia) may have important gender implications. The dislocations created by the transitional process in both the Russian Federation and the Ukraine triggered inter-enterprise payment arrears as enterprises were faced with hardened budget constraints that ultimately lead to the emergence of employee wage arrears. Enterprise managers could have used wage arrears as a discriminatory tool favouring male workers. The focus on wages paid may be misleading but data limitations confine the analysis to wages paid rather than wages due. As noted by Glinskaya and Mroz (1996), the effect of payment arrears on the gender pay gap is ambiguous but the inclusion of occupational controls may serve to mitigate such effects. 


\subsection{Empirical Estimates of the Gender Pay Gap}

Table 1 contains gender pay ratios based on expression [1] for seventeen countries undergoing transitional change. The data are based on monthly earnings and are obtained from a variety of international and national sources. For some of these countries we also report ratios from the period of central planning using gender pay ratio estimates from Atkinson and Micklewright (1992), who used data from the late 1980s. It should be noted that monthly ratios tend to be lower than ratios based on an hourly measure as men, on average, work longer hours than women. Despite this consideration, most of the reported ratios are relatively high compared to Western countries. They also suggest a mild contraction in the unadjusted gender pay gap since the introduction of reforms in Hungary, Poland, the Czech Republic and Slovakia. The ratios for Russia, Romania, Slovenia, the FR Yugoslavia and Kyrgystan are characterised by relative stability over the transitional period whilst the Bulgarian ratio registers a fall of five percentage points. The average monthly female earnings for the most recent years for Latvia, Lithuania, Estonia, the Ukraine and Uzbekistan range from twothirds to just over three quarters of male earnings and suggest little movement in this gap since the period of central planning.

The table provides contrasting country experiences in terms of the size and evolution of the gender pay gap. This type of summary analysis of the gender pay ratio, however, may provide a misleading picture of the female labour market position. Evidence of a stable or contracting gap may be due to the influence exerted by measured and/or unmeasured selection effects. For instance, a contraction in the gender pay gap may be partly attributable to the withdrawal from the transitional labour markets of poorly qualified women (see Hunt (1998)).

Eleven transitional countries provide the basis for our individual-level analysis and these are Bulgaria, Czech Republic, Hungary, Poland, Slovakia, the Federal Republic of Yugoslavia, Latvia, Russia, the Ukraine, Kazakhstan, and Uzbekistan. In the case of the Czech Republic, Hungary, Slovakia, and Uzbekistan the surveys only reported monthly earnings without information on monthly hours worked. All other survey data allowed us to compute our preferred hourly wage gap measure.

Table 2 reports a selection of gender pay gaps for these countries over a number of years. The first column of estimates reports the gender pay gap (rather than ratios) unadjusted for controls of any kind 
(i.e., $\overline{\mathrm{D}}$ in expression 2). If we look at the estimates for the $1990 \mathrm{~s}$, the unadjusted hourly pay gaps range from just over 10\% for Yugoslav employees to about 35\% for Bulgarian employees.

The second column of this table reports the gender pay gaps based on the estimate from a pooled equation that includes only human capital controls (i.e., education and the proxies for labour force experience). The fits of the estimated pooled hourly equations, as measured by the adjusted- $\mathrm{R}^{2}$, vary from 0.04 for Russia to 0.19 for FR Yugoslavia - both for 1996. The fits for the pooled monthly equations vary from 0.15 in Uzbekistan to 0.42 for the Czech Republic. All the estimated gender effects are statistically significant at a conventional level. For most countries there is little movement in the gender pay gap once allowance is made for the set of human capital controls. However, in the cases of Latvia, Poland, Russia and the Ukraine, a steep rise in the adjusted gender pay gap is observed relative to the unadjusted measure. This suggests, particularly for these countries, that women's education levels are probably slightly higher than men's, so controlling for this reveals a larger gender pay gap.

The third and fourth columns of table 2 provide estimates for the gender pay gap based on expressions [8] and [9] respectively with standard errors reported in parentheses. $\mathrm{Z}$ and $\hat{\alpha}$ denote the vectors of human capital characteristics and estimated coefficients respectively. The separate estimation of wage equations offers no new insights with the estimates for [8] and [9] dimensionally comparable to the pooled estimate in almost all cases. All the estimated effects are again significant and the estimates do not appear all that sensitive to the vector of characteristics used.

The fifth column of table 2 reports the estimated gender effect for specifications augmented to include additional controls. One has to be cautious in interpreting the estimates in this column, however, since the augmented controls are not identical across all countries. In most cases they do include controls for occupations, industry, and region. The inclusion of additional wage determining variables enhances the fits in most cases. The magnitude of the gender effect declines in most countries once these controls are entered but actually increases in the case of Uzbekistan. In all cases, however, the estimated gender effects remain statistically significant.

The sixth and seventh columns of table 2 provide estimates for the gender pay gap based on expressions [8] and [9] respectively with standard errors reported in parentheses. $X$ and $\hat{\beta}$ denote the vectors of characteristics and estimated coefficients respectively in this case. The picture remains 
William Davidson Institute Working Paper Number 305

broadly the same as column five although there is now some evidence of sensitivity in the estimates depending on which vector of characteristics is used. Nevertheless, one generalization offered by the table is that for all transitional countries, most of the average gender pay gap is attributed to treatment effects rather than differences in endowments. One can only speculate as to how much of the differential assigned to the treatment component is due to our inappropriate measurement of female labour force experience. It is evident that there would be significant differences in the endowment of this particular variable by gender, so it is worth bearing this in mind in interpreting this set of results.

\section{Quantile Regression Results}

The methodologies outlined up to now rely entirely on the decomposition of a mean regression. An exclusive focus on the average may provide misleading insights into the gender pay gap. The quantile regression approach (see, Chamberlain (1994)) provides a framework within which the ceteris paribus gender pay gap can be estimated at a particular quantile of the distribution as opposed to simply the mean. The applicability of quantile regression techniques has been limited by computational constraints. This is no longer the case and median regression can be defined by minimizing the absolute sums of the errors rather, as in least squares, minimizing the sum of squares. The estimator is known as the Least Absolute Deviations or LAD estimator. If we return to our pooled specification and introduce the $i$ subscripts for $i=1, \ldots, n$, we could re-write [3] as:

$\mathbf{w}_{\mathbf{i}}=\mathbf{X}_{\mathbf{i}}^{\prime} \beta+\delta \mathbf{G}_{\mathbf{i}}+\mathbf{e}_{\mathbf{i}}$

The median regression coefficients can be obtained by choosing the values that minimize $\mathrm{L}$

$\mathrm{L}=\sum_{\mathrm{i}=1}^{\mathrm{n}}\left|\mathrm{w}_{\mathrm{i}}-\mathrm{X}_{\mathrm{i}}^{\prime} \beta-\delta \mathrm{G}_{\mathrm{i}}\right|=\sum_{\mathrm{i}=1}^{\mathrm{n}}\left(\mathrm{w}_{\mathrm{i}}-\mathrm{X}_{\mathrm{i}}^{\prime} \beta-\delta \mathrm{G}_{\mathrm{i}}\right) \operatorname{sgn}\left(\mathrm{w}_{\mathrm{i}}-\mathrm{X}^{\prime} \beta-\delta \mathrm{G}_{\mathrm{i}}\right)$

Where $\operatorname{sgn}(a)$ is the sign of a, 1 if a is positive, and -1 if a is negative or zero.

The computation of the estimates is a linear programming problem. In contrast to the OLS approach, the quantile regression procedure is less sensitive to outliers and provides a more robust estimator in the face of departures from normality (see Koenker and Bassett (1978)). Quantile regression models may also have better properties than OLS in the presence of heteroscedasticity. It is desirable to 
explore quantile regressions other than the median. Using this methodology, the log wage equation is estimated conditional on a given specification and then calculated at various percentiles of the residuals (e.g., the $10^{\text {th }}$, the $25^{\text {th }}$, the $75^{\text {th }}$ or the $90^{\text {th }}$ ) by minimizing the sum of absolute deviations of the residuals from the conditional specification. In the context of the regression model specified, quantile regression estimation would allow the estimation of the $\delta$ parameter at the $10^{\text {th }}, 25^{\text {th }}, 50^{\text {th }}$, $75^{\text {th }}$ and $90^{\text {th }}$ percentile. Estimates for $\delta$ obtained in this manner would allow the investigator to establish the magnitude of the ceteris paribus gender pay gap at different points of the wage distribution. This could be important if it was felt that the average provided a misleading picture.

Given our findings in the last section, there appears little loss in modelling earnings for our set of transitional countries using the type of pooled specification described in [10]. Table 3 provides estimates for a set of quantile regressions at the median, the $10^{\text {th }}, 25^{\text {th }}, 75^{\text {th }}$ and the $90^{\text {th }}$ percentiles. The log wage quantile regression at, for instance, the $10^{\text {th }}$ percentile predicts the value of the log wage at the 10th percentile rather than at the mean and the interpretation of the gender dummy is the percent (or log point) difference, ceteris paribus, between the male and female 10th percentile wage. For completeness, the table also reports the estimated gender effect at the mean, which was reported earlier in table 2. Estimates are again reported for two specifications: the basic human capital model and the specification augmented by the inclusion of additional wage determining controls.

For most countries, there is little material difference between the mean and median regression estimates. One exception is Russia for 1996 where a $0.068 \log$ point difference in the gender effect is reported but in comparison to the estimated standard errors for these estimates this difference is not viewed as sizeable. An examination of the estimated gender effect over the different percentiles provides some insight into the ceteris paribus gender pay gap in low paid jobs $\left(10^{\text {th }}\right.$ percentile $)$ and in high paid jobs $\left(90^{\text {th }}\right.$ percentile). For convenience, we only focus on the estimates from the augmented specifications. In most countries there is a steady rise in the estimated gender pay gap as we move from low-paid to high-paid jobs. The most dramatic increase in the gap between the $90^{\text {th }}$ and $10^{\text {th }}$ percentiles is reported for Kazakstan where the difference is of the order of $0.33 \mathrm{log}$ points. Other sizeable differences are reported for Uzbekistan (0.186 log points) and for Russia in 1996 (0.142 log points). In marked contrast to all other countries reported, the estimates for the Ukraine suggest a steady decline as we move across the distribution with the ceteris paribus gender pay gap declining by about $0.168 \log$ points between the $10^{\text {th }}$ and the $90^{\text {th }}$ percentile. 


\section{The Evolution of the Gender Pay Gap}

Juhn, Murphy and Pierce (1991) provide an additional dimension to decomposing the gender pay gap, which introduces a temporal dimension to the analysis. The 'unexplained' or 'residual' differential can be decomposed further into a part attributable to differences in percentile rankings within the residual wage distribution and to a part due to wage dispersion. The advantage of adopting the extended decomposition suggested by Juhn et al. is that it facilitates an examination of the factors that influence the gender pay gap over time.

Assume the following male wage equation for worker $\mathrm{i}$ in year $\mathrm{t}$ :

$\mathbf{w}_{\mathrm{it}}=\mathbf{X}_{\mathrm{it}}{ }^{\prime} \beta_{\mathrm{t}}+\mathbf{u}_{\mathrm{it}}$

or

$\mathbf{w}_{\mathrm{it}}=\mathbf{X}_{\mathrm{it}} \beta_{\mathrm{t}}+\sigma_{\mathrm{t}} \theta_{\mathrm{it}}$

where:

$\mathbf{w}_{\mathbf{i t}} \quad=$ natural logarithm of wages for individual $\mathrm{i}$ at time $\mathrm{t}$;

$\mathbf{X}_{\mathbf{i t}} \quad=$ vector of explanatory variables for individual $\mathrm{i}$ at time $\mathrm{t}$;

$\beta_{\mathrm{t}} \quad=$ vector of male coefficients at time $\mathrm{t}$;

$\sigma_{\mathrm{t}} \quad=$ the residual standard deviation of male wages;

$\theta_{\text {it }}=$ standardized residual with a mean of zero and a standard deviation of 1 (i.e. $u_{i t} \div \sigma_{\mathrm{t}}$ given the average residual is zero)

In average terms, and with $\mathrm{m}$ and $\mathrm{f}$ denoting male and female respectively, the gender wage gap for year $t$ (denoted by $\overline{\mathrm{D}}_{\mathrm{t}}$ ) is given by:

$\overline{\mathrm{D}}_{\mathrm{t}}=\overline{\mathrm{W}}_{\mathrm{mt}}-\overline{\mathrm{W}}_{\mathrm{ft}}=\Delta \overline{\mathrm{X}}_{\mathrm{t}} \hat{\beta}+\sigma_{\mathrm{t}} \Delta \bar{\theta}_{\mathrm{t}}$

where:

$\Delta \overline{\mathrm{X}}_{\mathrm{t}}=\overline{\mathrm{X}}_{\mathrm{mt}}-\overline{\mathrm{X}}_{\mathrm{ft}}$ 
and:

$\Delta \bar{\theta}=\frac{\overline{\mathrm{W}}_{\mathrm{m} t}-\overline{\mathrm{X}}_{\mathrm{m}} \hat{\beta}^{\hat{\beta}}}{\sigma \mathrm{T}}-\frac{\overline{\mathrm{W}}_{\mathrm{t}}-\overline{\mathrm{X}}_{\mathrm{t}} \hat{\beta}^{\hat{\beta}}}{\sigma \mathrm{t}}$

with bars denoting mean values and hats the OLS estimates.

The first component of the final part of expression [13] provides an estimate of the portion of the average gender wage gap attributable to differences in observable characteristics; the final component is usually interpreted as the discrimination effect. This is a simple re-expression of the 'index number' decomposition encountered in expression [7]. The difference in this gap between two years (for example, 1996 and 1992) can be decomposed using [13] as:

$$
\begin{gathered}
\overline{\mathrm{D}}_{96}-\overline{\mathrm{D}}_{92}=\left[\Delta \overline{\mathrm{X}}_{96}-\Delta \overline{\mathrm{X}}_{92}\right] \hat{\beta}_{96}+\left[\Delta \overline{\mathrm{X}}_{92}\right]\left(\hat{\beta}_{96-} \hat{\beta}_{92}\right) \\
+\sigma_{96}\left\{\Delta \bar{\theta}_{96}-\Delta \bar{\theta}_{92}\right\}+\Delta \bar{\theta}_{92}\left(\hat{\beta}_{96}-\hat{\beta}_{92}\right)
\end{gathered}
$$

The first term captures the effect of changes in observable characteristics over time on the gender wage gap (e.g., changes in skill quantities like education and labour force experience); the second term captures the effect of changes in observable prices over time on the gender wage gap (e.g., changes in skill prices like the returns to education and experience); the third term captures what is called the 'gap effect' which measures the impact of changes in the relative position of men and women in the residual wage distribution on the gender wage gap; the fourth term reflects the role of changes in residual wage inequality on the gender wage gap. The first and third terms measure gender specific factors, the second and fourth terms measure 'wage structure' effects. In a traditional wage decomposition framework, the third and fourth terms are commonly interpreted as providing estimates of discrimination. The procedure requires the estimation of male wage equations for each year of interest. The decomposition, as expressed in [14], relies on the properties of the Ordinary Least Squares (OLS) estimator. In addition, only male coefficients are used in this analysis since they could be viewed as providing 'cleaner' estimates of the prices for the quantities used in our analysis given they are less likely to be influenced by discriminatory processes that may be at work. 
Juhn et al. (1991, 1993) and Blau and Khan (1992, 1994 and 1996) interpret the last two terms of expression [17] as reflecting the effects of unmeasured skills and prices respectively. Suen (1997) argues that such an interpretation is only valid if the percentile rankings are independent of the standard deviation of the wage residuals. However, this cannot be the case since the change in the 'gap effect' could not have occurred in the absence of a change in wage dispersion. This does not vitiate applying the decomposition but highlights a requirement for caution in the economic interpretation attached to these terms. In particular, the use of these terms to provide inferences on changes in unobservable prices and quantities is prone to error and the tendency of some authors to interpret the 'gap effect' independently of the dispersion effect as indicative of progress on the part of women is demonstrably unjustified.

The movement of the gender pay gap in the economies undergoing transitional change has recently been the subject of empirical investigation. Orasem and Vodopivec (1995, 1999), Reilly (1999) and Hunt (1998) have provided insights into its evolution for Slovenia, Sovenia and Estonia, Russia and East Germany respectively. In this paper, we look at just two countries: Russia and FR Yugoslavia.

The decompositions reported in table 4 are based on hourly wages and the mean regression for the augmented specification using the sample of male workers only. The years of comparison are 1992 and 1996 for Russia, and 1995 and 1996 for the Federal Republic of Yugoslavia. A negative entry indicates an effect that reduces the gender pay gap.

In both cases the changes in the gender pay gap have been negligible. The contribution of changes in observed characteristics is small suggesting little evidence of a selection effect in observable variables. The effect of wage dispersion on the gender pay gap is most pronounced in Russia but is offset by movements in returns to human capital that appear favourable to women. On the basis of these two transitional economies, and over the time period examined, there is little evidence of anything more than minor movements in the observed gender pay gap. These results are broadly in line with the findings of Orasem and Vodopivec $(1995,1999)$ for Slovenia and Estonia and Reilly (1999) for Russia. 


\section{$5 \quad$ Conclusions}

The review of the evidence and the analysis undertaken suggests that, in general, the gap in pay between men and women in the transitional countries is low by international standards. Our use of age as a proxy for labour force experience is accepted as questionable and may assign more to the gender effect than is actually justified. This could be taken to suggest that the actual adjusted gender pay gap estimates are, if anything, lower than those reported in this paper.

On the basis of the evidence, it could be argued that, although there are marked contrasts in the relative wage position of the average woman across the transitional economies, the adjustment process itself appears, heretofore, to have been approximately neutral to female pay position relative to the average male. This is perhaps most surprising for Russia and other CIS countries where there have been large increases in wage inequality. It seems that in these countries, contrary to expectation, the relative pay position of women has not worsened on average.

Hunt (1998), looking at data from former East Germany, highlights the importance of selection effects when interpreting movements in the gender pay gap. In the four years subsequent to unification, the wages of East German women rose by ten percentage points relative to men. Hunt estimates that four-fifths of this rise was attributable to a selection effect caused by the withdrawal from employment of poorly qualified women. This raises the question whether the apparent stability of the average gender pay gap observed for other transitional economies conceals more important underlying movements in the labour market status of women. Although the data available is limited and prevents a deeper analysis of this issue, the message from other countries is the East German experience is atypical. The departure from the German labour market of poorly qualified women is facilitated by the existence of a much more generous social safety net in Germany than currently in existence in the other transitional countries. Although selection effects may be present in our data, current labour market conditions and the necessity for households to have dual income earners have prevented a widespread departure from work of poorly qualified women. This is confirmed by the fact, as highlighted in an earlier section, that the female share of employment has remained relatively constant in most economies over the transitional period.

The quantile regression analysis undertaken provided an insight into the ceteris paribus gender pay gap as we move across the wage distribution. In all but one country, there was evidence of larger 
William Davidson Institute Working Paper Number 305

gaps in the higher paid jobs relative to the lower paid jobs. This general result flags an important and clearly justifies further research.

In framing the analysis purely in terms of gender pay differentials, it is important to note that pay gaps within gender groups are also important. Waldfogel (1998a) identifies a widening family wage gap for young cohorts of women where young women with children in the United States have higher gender pay gaps than women without children. Waldfogel (1998b) also found that job-protected maternity leave offsets the negative wage effects of having children in both the United States and Great Britain. This is clearly an issue worthy of investigation for the transitional economies where the provision of job-protected maternity leave is unlikely to represent a key priority to employers as private sector employment grows.

Finally, it is salutary to note that the gender pay gap appears to have exhibited a degree of stability over a very volatile period in the post-centralization era in most transitional economies. Nevertheless, the gender dimension of employment and unemployment has not been explored in this paper nor have the effects of enterprise re-structuring, the re-shaping of the social safety net, and the reform of family benefits. Together these have clear implications for the welfare of women. It may be the case that time will show that these factors exert more important influences on the welfare of women in transitional economies than the evolution of the gender pay gap. 
Table 1: Monthly Gender Pay Ratios in Transitional Economies for Selected Years

\begin{tabular}{|c|c|c|}
\hline Country & Year & Ratio \\
\hline \multirow[t]{3}{*}{ Czech Republic $^{\text {a) }}$} & 1987 & 0.661 \\
\hline & 1992 & 0.730 \\
\hline & 1996 & 0.813 \\
\hline \multirow[t]{3}{*}{ Hungary b) } & 1986 & 0.743 \\
\hline & 1992 & 0.808 \\
\hline & 1996 & 0.789 \\
\hline \multirow[t]{3}{*}{ Poland $^{c)}$} & 1985 & 0.737 \\
\hline & 1992 & 0.790 \\
\hline & 1996 & 0.790 \\
\hline \multirow[t]{3}{*}{ Slovakia $^{\text {d) }}$} & 1987 & 0.661 \\
\hline & 1992 & 0.733 \\
\hline & 1996 & 0.782 \\
\hline \multirow[t]{3}{*}{ Bulgaria e) } & 1990 & 0.740 \\
\hline & 1995 & 0.700 \\
\hline & 1997 & 0.691 \\
\hline \multirow[t]{2}{*}{ Romania $^{\text {f) }}$} & 1994 & 0.786 \\
\hline & 1996 & 0.760 \\
\hline \multirow[t]{3}{*}{ Slovenia $^{\mathrm{g})}$} & 1987 & 0.870 \\
\hline & 1991 & 0.905 \\
\hline & 1996 & 0.869 \\
\hline \multirow[t]{3}{*}{ FR Yugoslavia ${ }^{\text {h) }}$} & 1995 & 0.899 \\
\hline & 1996 & 0.888 \\
\hline & 1997 & 0.884 \\
\hline Estonia $^{i)}$ & 1997 & 0.750 \\
\hline Latvia $^{\mathrm{j} \text { ) }}$ & 1997 & 0.799 \\
\hline \multirow[t]{2}{*}{ Lithuania $^{\text {k) }}$} & 1997 & $0.650(\mathrm{~m})$ \\
\hline & & $0.710(\mathrm{n})$ \\
\hline \multirow[t]{3}{*}{ Russia $^{\text {l) }}$} & 1989 & 0.709 \\
\hline & 1992 & 0.685 \\
\hline & 1996 & 0.695 \\
\hline Ukraine $^{\mathrm{m})}$ & 1996 & 0.777 \\
\hline Kazakhstan $^{\text {n) }}$ & 1996 & 0.723 \\
\hline \multirow[t]{3}{*}{ Kyrkgystan $^{\circ)}$} & 1995 & 0.733 \\
\hline & 1996 & 0.730 \\
\hline & 1997 & 0.720 \\
\hline Uzbekistan $^{\mathrm{p})}$ & 1995 & 0.805 \\
\hline
\end{tabular}

\section{Sources:}

a) Atkinson and Micklewright (1992) and Social Stratification Surveys. b) MONEE Database Project.

c) Atkinson and Micklewright (1992) and Polish Labour Force Surveys. d) Atkinson and Micklewright (1992) and Social Stratification Surveys. e) MONEE Database Project. f) MONEE Database Project. g) Orasem and Vodopivec (1995) and MONEE Database Project. h) FRY Labour Force Surveys. i) MONEE Database Project. j) MONEE Database Project. k) MONEE Database Project; $n$ and $m$ denotes manual and non-manual workers respectively. 1) Atkinson and Micklewright (1992) and Russian Longitudinal Monitoring Surveys. m) Ukraine Living Standards Measurement Survey. n) Kazakhstan Livings Standard Measurement Survey. o) MONEE Database Project. p) The European University Institute and Essex University Survey in Uzbekistan.

Notes. The MONEE Database Project is maintained at UNICEF's International Child Development Centre. See UNICEF (1999) for a reference. All the other data sources are either available from the World Bank's LSMS web site or were communicated to the authors, mostly from national statistical offices. The authors will respond to all reasonable data enquiries. 
Table 2: Gender Pay Gaps for Selected Transitional Economies

\begin{tabular}{|c|c|c|c|c|c|c|c|c|c|c|c|}
\hline Country & Year & $\begin{array}{l}\text { Pay } \\
\text { Measure }\end{array}$ & $\overline{\mathrm{D}}$ & $\hat{\delta}_{\mathrm{B}}$ & $\bar{Z}_{f}{ }^{\prime} \Delta \hat{\alpha}$ & $\bar{Z}_{\mathrm{m}}{ }^{\prime} \Delta \hat{\alpha}$ & $\hat{\delta}_{\mathrm{A}}$ & $\overline{\mathrm{X}}_{\mathrm{f}}{ }^{\prime} \Delta \hat{\beta}$ & $\overline{\mathrm{X}}_{\mathrm{m}}{ }^{\prime} \Delta \hat{\beta}$ & $\mathrm{N}_{\mathrm{f}}$ & $\mathrm{N}_{\mathrm{m}}$ \\
\hline Bulgaria & 1995 & Hourly & 0.301 & $\begin{array}{c}0.318 \\
(0.031)\end{array}$ & $\begin{array}{c}0.316 \\
(0.030)\end{array}$ & $\begin{array}{c}0.313 \\
(0.032)\end{array}$ & $\begin{array}{c}0.248 \\
(0.034)\end{array}$ & $\begin{array}{c}0.216 \\
(0.035)\end{array}$ & $\begin{array}{c}0.293 \\
(0.035)\end{array}$ & 834 & 944 \\
\hline Adjusted-R ${ }^{2}$ & & & & 0.099 & 0.086 & 0.036 & 0.138 & 0.107 & 0.106 & & \\
\hline $\begin{array}{l}\text { Czech } \\
\text { Republic }\end{array}$ & 1984 & Monthly & 0.377 & $\begin{array}{c}0.371 \\
(0.012)\end{array}$ & $\begin{array}{c}0.374 \\
(0.012)\end{array}$ & $\begin{array}{c}0.361 \\
(0.012)\end{array}$ & $\begin{array}{c}0.327 \\
(0.013)\end{array}$ & $\begin{array}{c}0.327 \\
(0.014)\end{array}$ & $\begin{array}{l}0.326 \\
(0.014)\end{array}$ & 956 & 1155 \\
\hline Adjusted-R ${ }^{2}$ & & & & 0.419 & 0.257 & 0.141 & 0.467 & 0.312 & 0.233 & & \\
\hline $\begin{array}{l}\text { Czech } \\
\text { Republic }\end{array}$ & 1992 & Monthly & 0.316 & $\begin{array}{c}0.312 \\
(0.014)\end{array}$ & $\begin{array}{c}0.308 \\
(0.014)\end{array}$ & $\begin{array}{c}0.316 \\
(0.014)\end{array}$ & $\begin{array}{c}0.282 \\
(0.015)\end{array}$ & $\begin{array}{c}0.254 \\
(0.021)\end{array}$ & $\begin{array}{c}0.311 \\
(0.017)\end{array}$ & 1406 & 1610 \\
\hline Adjusted-R ${ }^{2}$ & & & & 0.263 & 0.182 & 0.135 & 0.339 & 0.278 & 0.222 & & \\
\hline Hungary & 1992 & Monthly & 0.226 & $\begin{array}{c}0.246 \\
(0.018)\end{array}$ & $\begin{array}{c}0.248 \\
(0.020)\end{array}$ & $\begin{array}{c}0.249 \\
(0.019)\end{array}$ & $\begin{array}{c}0.210 \\
(0.020)\end{array}$ & $\begin{array}{c}0.186 \\
(0.026)\end{array}$ & $\begin{array}{c}0.251 \\
(0.023)\end{array}$ & 833 & 903 \\
\hline Adjusted-R ${ }^{2}$ & & & & 0.313 & 0.290 & 0.248 & 0.378 & 0.366 & 0.316 & & \\
\hline Kazakhstan & 1996 & Hourly & 0.197 & $\begin{array}{c}0.246 \\
(0.057)\end{array}$ & $\begin{array}{c}0.263 \\
(0.060)\end{array}$ & $\begin{array}{c}0.245 \\
(0.057)\end{array}$ & $\begin{array}{c}0.270 \\
(0.052)\end{array}$ & $\begin{array}{c}0.303 \\
(0.055)\end{array}$ & $\begin{array}{c}0.247 \\
(0.056)\end{array}$ & 572 & 624 \\
\hline Adjusted-R ${ }^{2}$ & & & & 0.052 & 0.054 & 0.033 & 0.180 & 0.133 & 0.205 & & \\
\hline Latvia & 1996 & Hourly & 0.190 & $\begin{array}{c}0.238 \\
(0.027)\end{array}$ & $\begin{array}{c}0.244 \\
(0.027)\end{array}$ & $\begin{array}{c}0.222 \\
(0.027)\end{array}$ & $\begin{array}{c}0.234 \\
(0.028)\end{array}$ & $\begin{array}{c}0.249 \\
(0.029)\end{array}$ & $\begin{array}{c}0.212 \\
(0.036)\end{array}$ & 853 & 863 \\
\hline Adjusted-R ${ }^{2}$ & & & & 0.144 & 0.129 & 0.125 & 0.265 & 0.272 & 0.233 & & \\
\hline Poland & 1992 & Hourly & 0.095 & $\begin{array}{c}0.190 \\
(0.007)\end{array}$ & $\begin{array}{c}0.172 \\
(0.009)\end{array}$ & $\begin{array}{c}0.205 \\
(0.007)\end{array}$ & $\begin{array}{c}0.182 \\
(0.007)\end{array}$ & $\begin{array}{c}0.164 \\
(0.009)\end{array}$ & $\begin{array}{c}0.196 \\
(0.007)\end{array}$ & 7003 & 8364 \\
\hline Adjusted-R ${ }^{2}$ & & & & 0.266 & 0.343 & 0.196 & 0.274 & 0.205 & 0.351 & & \\
\hline Poland & 1996 & Hourly & 0.131 & $\begin{array}{l}0.215 \\
(0.006)\end{array}$ & $\begin{array}{c}0.202 \\
(0.007)\end{array}$ & $\begin{array}{l}0.228 \\
(0.006)\end{array}$ & $\begin{array}{c}0.174 \\
(0.006)\end{array}$ & $\begin{array}{c}0.162 \\
(0.007)\end{array}$ & $\begin{array}{l}0.209 \\
(0.009)\end{array}$ & 7202 & 8611 \\
\hline Adjusted-R ${ }^{2}$ & & & & 0.314 & 0.377 & 0.445 & 0.399 & 0.244 & 0.355 & & \\
\hline
\end{tabular}


William Davidson Institute Working Paper Number 305

\section{Table 2 (cont'd)}

\begin{tabular}{|c|c|c|c|c|c|c|c|c|c|c|c|}
\hline Adjusted-R ${ }^{2}$ & 1992 & Hourly & 0.251 & $\begin{array}{c}0.302 \\
(0.021) \\
\\
0.071\end{array}$ & $\begin{array}{c}0.315 \\
(0.021) \\
\\
0.044\end{array}$ & $\begin{array}{c}0.305 \\
(0.021) \\
\\
0.052\end{array}$ & $\begin{array}{c}0.200 \\
(0.024) \\
\\
0.163\end{array}$ & $\begin{array}{c}0.226 \\
(0.030) \\
\\
0.125\end{array}$ & $\begin{array}{c}0.185 \\
(0.027) \\
\\
0.165\end{array}$ & 2800 & 2863 \\
\hline Russia & 1996 & Hourly & 0.244 & $\begin{array}{c}0.299 \\
(0.046)\end{array}$ & $\begin{array}{c}0.297 \\
(0.049)\end{array}$ & $\begin{array}{c}0.299 \\
(0.048)\end{array}$ & $\begin{array}{c}0.230 \\
(0.052)\end{array}$ & $\begin{array}{c}0.289 \\
(0.060)\end{array}$ & $\begin{array}{c}0.191 \\
(0.059)\end{array}$ & 1013 & 908 \\
\hline Adjusted- $\mathrm{R}^{2}$ & & & & 0.041 & 0.022 & 0.031 & 0.127 & 0.118 & 0.123 & & \\
\hline Slovakia & 1984 & Monthly & 0.332 & $\begin{array}{c}0.333 \\
(0.016)\end{array}$ & $\begin{array}{c}0.335 \\
(0.017)\end{array}$ & $\begin{array}{c}0.329 \\
(0.017)\end{array}$ & $\begin{array}{c}0.309 \\
(0.018)\end{array}$ & $\begin{array}{c}0.321 \\
(0.022)\end{array}$ & $\begin{array}{c}0.294 \\
(0.024)\end{array}$ & 466 & 557 \\
\hline Adjusted-R ${ }^{2}$ & & & & 0.400 & 0.207 & 0.189 & 0.427 & 0.273 & 0.213 & & \\
\hline Slovakia & 1992 & Monthly & 0.310 & $\begin{array}{c}0.322 \\
(0.017)\end{array}$ & $\begin{array}{c}0.321 \\
(0.017)\end{array}$ & $\begin{array}{c}0.325 \\
(0.018)\end{array}$ & $\begin{array}{c}0.310 \\
(0.020)\end{array}$ & $\begin{array}{c}0.290 \\
(0.026)\end{array}$ & $\begin{array}{c}0.363 \\
(0.022)\end{array}$ & 653 & 1204 \\
\hline Adjusted-R ${ }^{2}$ & & & & 0.245 & 0.174 & 0.105 & 0.304 & 0.263 & 0.178 & & \\
\hline Ukraine & 1996 & Hourly & 0.186 & $\begin{array}{c}0.244 \\
(0.052)\end{array}$ & $\begin{array}{c}0.236 \\
(0.053)\end{array}$ & $\begin{array}{c}0.246 \\
(0.053)\end{array}$ & $\begin{array}{c}0.202 \\
(0.056)\end{array}$ & $\begin{array}{c}0.180 \\
(0.063)\end{array}$ & $\begin{array}{c}0.160 \\
(0.069)\end{array}$ & 496 & 500 \\
\hline Adjusted-R ${ }^{2}$ & & & & 0.083 & 0.085 & 0.069 & 0.137 & 0.122 & 0.148 & & \\
\hline Uzbekistan & 1995 & Monthly & 0.216 & $\begin{array}{c}0.216 \\
(0.032)\end{array}$ & $\begin{array}{c}0.213 \\
(0.032)\end{array}$ & $\begin{array}{c}0.218 \\
(0.032)\end{array}$ & $\begin{array}{c}0.261 \\
(0.030)\end{array}$ & $\begin{array}{c}0.261 \\
(0.030)\end{array}$ & $\begin{array}{c}0.260 \\
(0.031)\end{array}$ & 696 & 886 \\
\hline Adjusted-R ${ }^{2}$ & & & & 0.155 & 0.175 & 0.123 & 0.297 & 0.305 & 0.269 & & \\
\hline Yugoslavia & 1995 & Hourly & 0.102 & $\begin{array}{c}0.120 \\
(0.018)\end{array}$ & $\begin{array}{c}0.119 \\
(0.018)\end{array}$ & $\begin{array}{c}0.112 \\
(0.018)\end{array}$ & $\begin{array}{c}0.113 \\
(0.019)\end{array}$ & $\begin{array}{c}0.107 \\
(0.021)\end{array}$ & $\begin{array}{c}0.128 \\
(0.022)\end{array}$ & 1299 & 1950 \\
\hline Adjusted-R ${ }^{2}$ & & & & 0.177 & 0.200 & 0.152 & 0.264 & 0.299 & 0.231 & & \\
\hline Yugoslavia & 1996 & Hourly & 0.116 & $\begin{array}{c}0.139 \\
(0.020)\end{array}$ & $\begin{array}{c}0.143 \\
(0.020)\end{array}$ & $\begin{array}{c}0.132 \\
(0.021)\end{array}$ & $\begin{array}{c}0.140 \\
(0.021)\end{array}$ & $\begin{array}{c}0.132 \\
(0.024)\end{array}$ & $\begin{array}{c}0.150 \\
(0.026)\end{array}$ & 1266 & 1930 \\
\hline Adjusted-R ${ }^{2}$ & & & & 0.194 & 0.197 & 0.182 & 0.267 & 0.293 & 0.242 & & \\
\hline
\end{tabular}




\section{William Davidson Institute Working Paper Number 305}

Notes to table 2:

1) Data Sources:

a) Bulgarian Household Budget Survey

b) Social Stratification Surveys

c) Social Stratification Surveys

d) Polish Labour Force Surveys

e) Social stratification Surveys

f) FRY Labour Force Surveys

g) Latvian Household Budget Survey

h) Russian Longitudinal Monitoring Surveys

i) Ukraine Living Standards Measurement Survey

j) Kazakhstan Labour Force Survey

k) The European University Institute and Essex University Survey in Uzbekistan

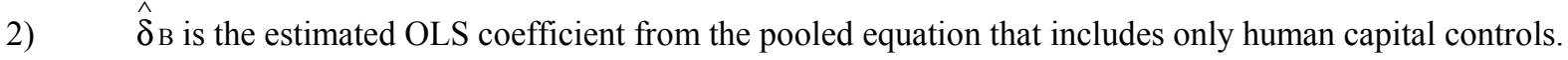

3) $\quad \hat{\delta}_{\mathrm{A}}$ is the estimated OLS coefficient from the pooled equation that includes human capital and other controls.

4) The $\mathrm{Z}$ vector includes only human capital controls; the $\mathrm{X}$ vector includes human capital and other controls.

5) The Adjusted- $\mathrm{R}^{2} \mathrm{~s}$ reported in columns two to seven refer to the basic pooled equation, the basic female equation, the basic male equation, the augmented pool equation, the augmented female equation, and the augmented male equation respectively.

6) $\quad \mathrm{N}_{\mathrm{f}}$ and $\mathrm{N}_{\mathrm{m}}$ refer to the female and male sample sizes respectively.

7) White (1980) standard errors are reported in parentheses.

8) The variance for the decompositions are computed as $\bar{Z}_{j}{ }^{\prime} \hat{V} \bar{Z}_{j}$ where $j=m$ or $f$, and $\hat{V}$ is the sum of the male and female variance-covariance matrices corrected for heteroscedasticity. 
Table 3: Quantile Regression Estimates of the Gender Pay Gaps for Selected Transitional Economies

\begin{tabular}{|c|c|c|c|c|c|c|c|c|c|c|}
\hline Country & Year & $\begin{array}{l}\text { Pay } \\
\text { Measure }\end{array}$ & Controls & Mean & $10^{\text {th }}$ & $25^{\text {th }}$ & $50^{\text {th }}$ & $75^{\text {th }}$ & $90^{\text {th }}$ & $\mathrm{N}$ \\
\hline Bulgaria & 1995 & Hourly & $\begin{array}{l}\text { Basic } \\
\text { All }\end{array}$ & $\begin{array}{c}0.318 \\
(0.031) \\
0.248 \\
(0.034)\end{array}$ & $\begin{array}{c}0.158 \\
(0.031) \\
0.144 \\
(0.032)\end{array}$ & $\begin{array}{c}0.232 \\
(0.023) \\
0.205 \\
(0.024)\end{array}$ & $\begin{array}{c}0.294 \\
(0.019) \\
0.235 \\
(0.020)\end{array}$ & $\begin{array}{c}0.336 \\
(0.023) \\
0.250 \\
(0.024)\end{array}$ & $\begin{array}{c}0.425 \\
(0.032) \\
0.273 \\
(0.038)\end{array}$ & 1778 \\
\hline $\begin{array}{l}\text { Czech } \\
\text { Republic }\end{array}$ & 1984 & Monthly & $\begin{array}{l}\text { Basic } \\
\text { All }\end{array}$ & $\begin{array}{c}0.371 \\
(0.012) \\
0.327 \\
(0.013) \\
\end{array}$ & $\begin{array}{c}0.366 \\
(0.153) \\
0.322 \\
(0.018) \\
\end{array}$ & $\begin{array}{c}0.369 \\
(0.011) \\
0.325 \\
(0.012)\end{array}$ & $\begin{array}{c}0.351 \\
(0.009) \\
0.321 \\
(0.010)\end{array}$ & $\begin{array}{c}0.365 \\
(0.011) \\
0.341 \\
(0.012)\end{array}$ & $\begin{array}{c}0.402 \\
(0.015) \\
0.331 \\
(0.017)\end{array}$ & 2111 \\
\hline $\begin{array}{l}\text { Czech } \\
\text { Republic }\end{array}$ & 1992 & Monthly & $\begin{array}{l}\text { Basic } \\
\text { All }\end{array}$ & $\begin{array}{c}0.312 \\
(0.014) \\
0.282 \\
(0.015)\end{array}$ & $\begin{array}{c}0.244 \\
(0.016) \\
0.236 \\
(0.018)\end{array}$ & $\begin{array}{c}0.292 \\
(0.012) \\
0.269 \\
(0.013)\end{array}$ & $\begin{array}{c}0.330 \\
(0.010) \\
0.299 \\
(0.011)\end{array}$ & $\begin{array}{c}0.352 \\
(0.012) \\
0.301 \\
(0.013)\end{array}$ & $\begin{array}{c}0.348 \\
(0.018) \\
0.320 \\
(0.019)\end{array}$ & 3016 \\
\hline Hungary & 1992 & Monthly & $\begin{array}{l}\text { Basic } \\
\text { All }\end{array}$ & $\begin{array}{c}0.246 \\
(0.018) \\
0.210 \\
(0.020)\end{array}$ & $\begin{array}{c}0.173 \\
(0.022) \\
0.181 \\
(0.024)\end{array}$ & $\begin{array}{c}0.239 \\
(0.016) \\
0.211 \\
(0.018)\end{array}$ & $\begin{array}{c}0.279 \\
(0.014) \\
0.212 \\
(0.015)\end{array}$ & $\begin{array}{c}c 0.271 \\
(0.017) \\
0.226 \\
(0.018)\end{array}$ & $\begin{array}{c}0.345 \\
(0.025) \\
0.253 \\
(0.027)\end{array}$ & 1736 \\
\hline Khazakstan & 1996 & Hourly & $\begin{array}{l}\text { Basic } \\
\text { All }\end{array}$ & $\begin{array}{c}0.246 \\
(0.057) \\
0.270 \\
(0.052)\end{array}$ & $\begin{array}{c}0.059 \\
(0.072) \\
0.178 \\
(0.063)\end{array}$ & $\begin{array}{c}0.164 \\
(0.049) \\
0.175 \\
(0.046)\end{array}$ & $\begin{array}{c}0.276 \\
(0.042) \\
0.272 \\
(0.039)\end{array}$ & $\begin{array}{c}0.517 \\
(0.051) \\
0.477 \\
(0.046)\end{array}$ & $\begin{array}{c}0.486 \\
(0.069) \\
0.508 \\
(0.065)\end{array}$ & 1196 \\
\hline Latvia & 1996 & Hourly & $\begin{array}{l}\text { Basic } \\
\text { All }\end{array}$ & $\begin{array}{c}0.238 \\
(0.027) \\
0.234 \\
(0.028)\end{array}$ & $\begin{array}{c}0.160 \\
(0.035) \\
0.195 \\
(0.037)\end{array}$ & $\begin{array}{c}0.226 \\
(0.026) \\
0.239 \\
(0.026)\end{array}$ & $\begin{array}{c}0.242 \\
(0.021) \\
0.250 \\
(0.022)\end{array}$ & $\begin{array}{c}0.279 \\
(0.026) \\
0.254 \\
(0.026)\end{array}$ & $\begin{array}{c}0.211 \\
(0.037) \\
0.224 \\
(0.037)\end{array}$ & 1716 \\
\hline Poland & 1992 & Hourly & $\begin{array}{l}\text { Basic } \\
\text { All }\end{array}$ & $\begin{array}{c}0.190 \\
(0.007) \\
0.182 \\
(0.007)\end{array}$ & $\begin{array}{c}0.141 \\
(0.008) \\
0.133 \\
(0.009) \\
\end{array}$ & $\begin{array}{c}0.173 \\
(0.006) \\
0.170 \\
(0.006) \\
\end{array}$ & $\begin{array}{c}0.215 \\
(0.005) \\
0.203 \\
(0.005) \\
\end{array}$ & $\begin{array}{c}0.235 \\
(0.006) \\
0.227 \\
(0.006)\end{array}$ & $\begin{array}{c}0.244 \\
(0.008) \\
0.235 \\
(0.009)\end{array}$ & 15367 \\
\hline Poland & 1996 & Hourly & $\begin{array}{l}\text { Basic } \\
\text { All }\end{array}$ & $\begin{array}{c}0.215 \\
(0.006) \\
0.174 \\
(0.006)\end{array}$ & $\begin{array}{c}0.137 \\
(0.008) \\
0.116 \\
(0.008)\end{array}$ & $\begin{array}{c}0.184 \\
(0.006) \\
0.152 \\
(0.006)\end{array}$ & $\begin{array}{c}0.231 \\
(0.005) \\
0.180 \\
(0.005)\end{array}$ & $\begin{array}{c}0.273 \\
(0.006) \\
0.216 \\
(0.006)\end{array}$ & $\begin{array}{c}0.296 \\
(0.008) \\
0.231 \\
(0.009)\end{array}$ & 15813 \\
\hline Russia & 1992 & Hourly & $\begin{array}{l}\text { Basic } \\
\text { All }\end{array}$ & $\begin{array}{c}0.302 \\
(0.021) \\
0.200 \\
(0.024)\end{array}$ & $\begin{array}{c}0.179 \\
(0.027) \\
0.099 \\
(0.030)\end{array}$ & $\begin{array}{c}0.282 \\
(0.019) \\
0.175 \\
(0.021)\end{array}$ & $\begin{array}{c}0.355 \\
(0.016) \\
0.194 \\
(0.018)\end{array}$ & $\begin{array}{c}0.377 \\
(0.028) \\
0.224 \\
(0.021)\end{array}$ & $\begin{array}{c}0.327 \\
(0.028) \\
0.225 \\
(0.031)\end{array}$ & 5663 \\
\hline Russia & 1996 & Hourly & $\begin{array}{l}\text { Basic } \\
\text { All }\end{array}$ & $\begin{array}{c}0.294 \\
(0.046) \\
0.218 \\
(0.052)\end{array}$ & $\begin{array}{c}0.225 \\
(0.062) \\
0.117 \\
(0.069)\end{array}$ & $\begin{array}{c}0.274 \\
(0.041) \\
0.196 \\
(0.047)\end{array}$ & $\begin{array}{c}0.364 \\
(0.034) \\
0.286 \\
(0.038)\end{array}$ & $\begin{array}{c}0.299 \\
(0.041) \\
0.293 \\
(0.045)\end{array}$ & $\begin{array}{c}0.265 \\
(0.059) \\
0.259 \\
(0.061)\end{array}$ & 1921 \\
\hline Slovakia & 1992 & Monthly & $\begin{array}{l}\text { Basic } \\
\text { All }\end{array}$ & $\begin{array}{c}0.333 \\
(0.016) \\
0.309 \\
(0.018) \\
\end{array}$ & $\begin{array}{c}0.331 \\
(0.021) \\
0.299 \\
(0.025) \\
\end{array}$ & $\begin{array}{c}0.335 \\
(0.015) \\
0.333 \\
(0.017) \\
\end{array}$ & $\begin{array}{c}0.336 \\
(0.012) \\
0.333 \\
(0.014) \\
\end{array}$ & $\begin{array}{c}0.330 \\
(0.015) \\
0.315 \\
(0.016) \\
\end{array}$ & $\begin{array}{c}0.345 \\
(0.021) \\
0.254 \\
(0.023) \\
\end{array}$ & 1023 \\
\hline Slovakia & 1992 & Monthly & $\begin{array}{l}\text { Basic } \\
\text { All }\end{array}$ & $\begin{array}{c}0.322 \\
(0.017) \\
0.310 \\
(0.020)\end{array}$ & $\begin{array}{c}0.317 \\
(0.020) \\
0.272 \\
(0.023)\end{array}$ & $\begin{array}{c}0.281 \\
(0.015) \\
0.289 \\
(0.016)\end{array}$ & $\begin{array}{c}0.317 \\
(0.012) \\
0.307 \\
(0.013)\end{array}$ & $\begin{array}{c}0.343 \\
(0.015) \\
0.330 \\
(0.016)\end{array}$ & $\begin{array}{c}0.395 \\
(0.021) \\
0.363 \\
(0.024)\end{array}$ & 1857 \\
\hline
\end{tabular}


William Davidson Institute Working Paper Number 305

Table 3 (Cont'd)

\begin{tabular}{|c|c|c|c|c|c|c|c|c|c|c|}
\hline Country & Year & $\begin{array}{l}\text { Pay } \\
\text { Measure }\end{array}$ & Controls & Mean & $10^{\text {th }}$ & $25^{\text {th }}$ & $50^{\text {th }}$ & $75^{\text {th }}$ & $90^{\text {th }}$ & $\mathrm{N}$ \\
\hline Ukraine & 1996 & Hourly & $\begin{array}{l}\text { Basic } \\
\text { All }\end{array}$ & $\begin{array}{c}0.244 \\
(0.052) \\
0.210 \\
(0.020) \\
\end{array}$ & $\begin{array}{c}0.253 \\
(0.070) \\
0.286 \\
(0.074)\end{array}$ & $\begin{array}{c}0.218 \\
(0.046) \\
0.228 \\
(0.050) \\
\end{array}$ & $\begin{array}{c}0.241 \\
(0.046) \\
0.255 \\
(0.042)\end{array}$ & $\begin{array}{c}0.240 \\
(0.046) \\
0.153 \\
(0.051) \\
\end{array}$ & $\begin{array}{c}0.291 \\
(0.062) \\
0.118 \\
(0.071) \\
\end{array}$ & 996 \\
\hline Uzbekistan & 1995 & Monthly & $\begin{array}{l}\text { Basic } \\
\text { All }\end{array}$ & $\begin{array}{c}0.216 \\
(0.032) \\
0.261 \\
(0.030) \\
\end{array}$ & $\begin{array}{c}0.073 \\
(0.050) \\
0.175 \\
(0.041) \\
\end{array}$ & $\begin{array}{c}0.141 \\
(0.029) \\
0.255 \\
(0.028) \\
\end{array}$ & $\begin{array}{c}0.151 \\
(0.024) \\
0.227 \\
(0.022) \\
\end{array}$ & $\begin{array}{c}0.271 \\
(0.028) \\
0.295 \\
(0.026) \\
\end{array}$ & $\begin{array}{c}0.420 \\
(0.040) \\
0.361 \\
(0.036) \\
\end{array}$ & 1582 \\
\hline Yugoslavia & 1995 & Hourly & $\begin{array}{l}\text { Basic } \\
\text { All }\end{array}$ & $\begin{array}{c}0.120 \\
(0.018) \\
0.113 \\
(0.019) \\
\end{array}$ & $\begin{array}{c}0.097 \\
(0.024) \\
0.106 \\
(0.025)\end{array}$ & $\begin{array}{c}0.113 \\
(0.016) \\
0.109 \\
(0.016) \\
\end{array}$ & $\begin{array}{c}0.101 \\
(0.013) \\
0.131 \\
(0.013) \\
\end{array}$ & $\begin{array}{c}0.143 \\
(0.016) \\
0.115 \\
(0.016) \\
\end{array}$ & $\begin{array}{c}0.139 \\
(0.022) \\
0.089 \\
(0.022) \\
\end{array}$ & 3249 \\
\hline Yugoslavia & 1996 & Hourly & $\begin{array}{l}\text { Basic } \\
\text { All }\end{array}$ & $\begin{array}{c}0.139 \\
(0.020) \\
0.140 \\
(0.021)\end{array}$ & $\begin{array}{c}0.159 \\
(0.028) \\
0.169 \\
(0.029)\end{array}$ & $\begin{array}{c}0.095 \\
(0.018) \\
0.097 \\
(0.019)\end{array}$ & $\begin{array}{c}0.122 \\
(0.015) \\
0.100 \\
(0.015)\end{array}$ & $\begin{array}{c}0.155 \\
(0.017) \\
0.126 \\
(0.018)\end{array}$ & $\begin{array}{c}0.197 \\
(0.023) \\
0.112 \\
(0.025)\end{array}$ & 3196 \\
\hline
\end{tabular}

Notes to table 3:

a) See notes to table 2 .

b) The Basic specification contains only human controls.

c) The All specification includes additional controls including region, occupations and industry.

d) Mean denotes the mean regression, $10^{\text {th }}, 25^{\text {th }}, 50^{\text {th }}, 75^{\text {th }}, 90^{\text {th }}$ denote the relevant percentile.

e) $\mathrm{N}$ is the sample size.

f) Quantile regression analysis undertaken using TSP (version 4.3) (See Hall (1996)). 
William Davidson Institute Working Paper Number 305

Table 4: The Gender Pay Gap over Time in Russia and Yugoslavia

\begin{tabular}{lcc}
\hline & Russia & FR Yugoslavia \\
\hline Observed Change & -0.007 & 0.014 \\
of which: & & \\
Observed Characteristics & -0.007 & -0.007 \\
Observed Prices & -0.043 & -0.004 \\
'Gap Effect' & -0.011 & 0.018 \\
Wage Dispersion & 0.054 & 0.006 \\
& & \\
of which: & & \\
Gender Specific & -0.018 & 0.012 \\
Wage Structure & 0.011 & 0.002 \\
\end{tabular}

Notes to table 4:

a) See notes to Table 2 .

b) The wage measure is the hourly wage and the specification is the augmented one.

c) The comparison is between 1996 and 1992 for Russia, and between 1996 and 1995 for Yugoslavia. 


\section{References}

Atkinson, A. and Micklewright, J. (1992), Economic Transformation in Eastern Europe and the Distribution of Income, Cambridge University Press.

Blau, F. D., and Kahn, L. M., (1992), The Gender Earnings Gap: Learning from International Comparisons, American Economic Review, Vol. 82, pp. 533-538.

Blau, F. D., and Kahn, L. M., (1994), Rising wage inequality and the US gender wage gap, American Economic Review, (Papers and Proceedings), Vol. 84, pp. 23-28.

Blau, F. D., and Kahn, L. M., (1996), Wage Structure and Gender Earnings Differentials, Economica, (Supplement on Economic Policy and Income Distribution), Vol. 63, pp. S29-S62.

Blinder, A.S. (1973), Wage Discrimination: Reduced Form and Structural Variables, Journal of Human Resources, Vol. 8, pp. 436-455.

Brainerd, E. (1998), Winners and Losers in Russia's Economic Transition, American Economic Review, Vol. 88, pp. 1094-1118.

Chamberlain, G. (1994), Quantile Regression, Censoring and the Structure of Wages in Proceedings of the Sixth World Congress of the Econometrics Society, Barcelona, Spain. New York: Cambridge University Press edited by C.Sims and J.J.Laffont.

Hall, B.H. (1996), Time Series Processor, Version 4.3, Reference Manual, Paolo Alto, California, USA.

Heckman, J. (1979), Sample Selection Bias as a Specification Error, Econometrica, Vol. 47, pp. 153161.

Hunt, J. (1998), The Transition in East Germany: When is a Ten Point Fall in the Gender Pay Gap Bad News? Discussion Paper Series in Transition Economics, No.1805.

Horton, S., Kanbur, R., and Mazumdar, D. (1991), Labour Markets in an Era of Adjustment: Evidence from 12 Developing Countries, International Labour Review, Vol. 130, pp.531-558.

Juhn, C., Murphy, K., and Brooks, P., (1991), Accounting for the Slowdown in Black-White Wage Convergence in M.Kosters (ed.) Workers and Their Wages, DC: American Enterprise Institute Press, pp.107-143.

Juhn, C., Murphy, K., and Brooks, P., (1993), Wage Inequality and the Rise in Returns to Skill, Journal of Political Economy, Vol. 101, pp. 410-442.

Koenker, R. and Bassett, G. (1978), Regression Quantiles, Econometrica, Vol. 46, No.1, pp.33-50.

Manski, C. (1989), Anatomy of the Selection Problem, Journal of Human Resources, Vol. 24, pp. 343-360. 
Newell, A. and Reilly, B. (1996), The Gender Wage Gap in Russia: Some Empirical Evidence, Labour Economics, Vol.3, No. 3 (October) pp. 337-356.

Oaxaca, R. L., (1973), Male-Female Wage Differentials in Urban Labour Markets, International Economic Review, Vol.14, pp. 693-709.

Orasem, P. and Vodopivec, M. (1995), Winners and Losers in Transition: Returns to Education, Experience, and Gender in Slovenia, World Bank Economic Review, Vol. 9, No.2, pp. 201-230.

Reilly, B. (1999), The Gender Pay Gap in Russia during the Transition, 1992-96, Economics of Transition, Vol. 7, No. 1, pp. 245-64.

Rutkowski, J. (1996), Changes in the Wage Structure During Economic Transition in Central and Eastern Europe, World Bank Technical Paper No.340 - Social Challenges of Transition Series.

Suen, W. (1997), Decomposing Wage Residuals: Unmeasured Skill or Statistical Artifact, Journal of Labor Economics, Vol. 15, pp. 555-566.

UNICEF (1999), Women in Transition, The MONEE Project Regional Monitoring Report, No. 6, ICDC, Florence, Italy.

Waldfogel, J. (1998,a), Understanding the Family Gap in Pay for Women with Children, Journal of Economic Perspectives, Vol. 12, No. 1 (Winter), pp. 137-156.

Waldfogel, J. (1998,b), The Family Gap in Pay for Young Women in the United States and Britain: Can Maternity Leave Make a Difference, Journal of Labor Economics, Vol. 16, No.3, pp. 505-545.

White, H. (1980), A Heteroscedastic-Consistent Covariance Matrix Estimator and a Direct Test for Heteroscedasticity, Econometrica, Vol. 48, pp. 817-838. 